\title{
Technology Transfer and Soviet Modernization (Using the Materials of Head Scientific Research Institutes)
}

\author{
E.A. Solentsova ${ }^{1, *}$ and A.A. Kapitonov ${ }^{1}$ \\ "Corresponding author: solentsova2009@mail.ru \\ ${ }^{1}$ Samara State University of Economics, Samara, Russia
}

\begin{abstract}
The article deals with the problems of technology transfer in the conditions of the "cold war". Along with the existing research in the field of technology transfer, the contribution to the understanding of Soviet modernization through the economic and technological cooperation between the USSR and the West in the 1950s and 1960s has been made. The focus of this work is on the transfer in the field of physical and chemical research. The authors studied the official documents of the head Research Institute of Physics and Chemistry named after L. Ya. Karpov in the Russian state archive in Samara. The available materials give examples of situations that initiated borrowing, show how these situations were implemented, interacted with each other. The authors traced the process of adaptation and institutional support of technology, using methods of analysis of transfers, consistently comparing the situation before and after borrowing, paying special attention to the phenomena arising "at the border".

The documents show that the political factor largely determined the nature of the technology transfer. The strategy of interaction with capitalist countries was built on the background of serious efforts of the Soviet political elite to present cooperation as only a demonstration of achievements of Soviet science and technology. At the same time, the desire of state bodies to ensure access of Soviet researchers to Western developments is a confirmation that it was possible to achieve the most effective results in cooperation. The logic of such relations, as the materials studied show, was built not only in the framework of state modernization programs, but also on the basis of research interests of scientists. The existing objective prerequisites, even in the conditions of ideological confrontation, contributed to the active network interaction of scientific community.
\end{abstract}

Keywords: technology transfer, modernization, Soviet economy, technological cooperation, the USSR, research institutes.

\section{Introduction}

The USSR took serious steps towards integration of domestic and foreign scientific and technical practice in the 1950-1960-ies. In conditions of ideological confrontation and scientific and technological revolution, the key role for the state was played by attempts reducing the time for the most important scientific developments. This contributed to the active expansion of the information space. The technological transfer as the process and movement of technologies, ideas, knowledge through state, social and institutional boundaries was a phenomenon that greatly contributed to the formation of a new technological paradigm in the second half of the 20th century. Its core, as we see it, includes the network logic and the beginning of a new modernization turn. Representations about the nature, content of the transfer are a very productive context for studying the economic history of the USSR. This is more topical because the history of the scientific and technical cooperation between the USSR and the West has to be rethought.

\section{Problem Statement}

Many Western researchers of the Cold War era considered the technological history of the USSR as a recipient of Western technologies and justified the inability of the Soviet economy to develop independently [1, 2]. As a result, scientific research has led to the emergence of new approaches to the study of the cooperation between the USSR and foreign countries in the scientific and technical sphere. The theses on the permeability of the Iron Curtain, put forward by Finnish scientists in the early 21 st century, are based on the notion of a "cold war" as a local collaboration of scientists, while maintaining a common confrontation at the global level [3]. S.V. Kuvshinov, exploring the experience of the military-technical cooperation between German and Soviet scientists in the era of postwar modernization, marked the current scientific and technological policy of the USSR in the field of the technology transfer as an effective "creative laboratory" [4].

To consider the problem of the technology transfer in conditions of the "cold war", the authors used materials from the funds of the Russian State Archive in Samara. The main sources were official documents of Karpov Institute of Physical Chemistry (NIFHI), subordinated to the Ministry of Chemical Industry of the USSR. This choice is due to the fact that the main scientific research institute was engaged in the most important developments in key areas of the economy, including research for the defense industry of the USSR. Achievements of Soviet scientists in the field of physics and chemistry in the mid-1950s were of a fundamental nature, but the level of competitiveness in practice could be achieved not only at the expense of discoveries themselves. To do this, it is necessary to use administrative, 
economic, legal, and political resources. The focus of this article is on the transfer between the USSR and the West in the field of physical and chemical research, although the collected materials do not cover the whole issue. The studied materials give examples of situations that initiated borrowing, show how these situations were realized, interacted with each other.

\section{Research Questions}

The main objectives of the study are to identify the role of central authorities in the transfer of foreign technologies, to consider the mechanisms of interaction, the circulation of knowledge and ideas, to substantiate the significance of the technology transfer in modernization processes of the USSR. Were the Soviet specialists able to get acquainted with technologies from abroad for study and familiarization?

\section{Purpose of the Study}

The purpose of this paper is to analyze the impact of the technology transfer on Soviet modernization in the 1950s1960s in conditions of the "cold war". On the basis of party and government documents, materials of the All-Union Leading Research Institutions, conclusions on the role of central authorities in technology transfer, the mechanisms of knowledge and ideas circulation are drawn.

\section{Research Methods}

Methodological approaches to the formation of the definition of the "technology transfer" are currently at the stage of substantiation and formulation of approaches to study. The technology transfer is considered at macro and micro levels. At the macro level, the transfer implies an international exchange of technologies, and at the micro level it is seen as a process of the technology transfer of "science-production" at the level of research institutes, universities, enterprises, etc. Since to date there is no clear separation of the concepts of the "technology transfer", "information transfer", it seems to us appropriate to consider these processes in aggregate, but not identifying them. The technology, in essence, is information, and the transfer is the diffusion of technologies in various ways: from state to state, from agency to department, from person to person. To some extent, this is the history of movement, mobility, network connections. As part of the study of transfers, it is possible to trace the adaptation process and the ability to institutionalize technology, consistently comparing the situation before and after borrowing, paying special attention to phenomena that arise "on the border" [5].

Is the transfer justified? Are technologies and ideas capable to be implemented in new conditions? It is important to consider the social factor in order to find the answers to these issues. In particular, the analysis of the correspondence of Soviet scientists with foreign colleagues in the 1950s-1960s was carried out through the prism of anthropological techniques. The technology cannot be applied without a human being, and modernization cannot be carried out without this technology. The existence in the social and technological single space is an integral part of modernization [6]. In addition, the authors used a combination of historical methods of analysis: historical-genetic and historical-comparative.

\section{Findings}

\subsection{Discussing technology transfer issues}

Based on the studied documents of the main research Karpov Institute of Physical Chemistry (NIFHI), the authors analyzed the directions of the international cooperation and technology transfer of the USSR in the 1950s-1960s. The Institute, located in Moscow, concentrated a number of the most important research directions of the country, relevant for the national and world science. Among them: solving the problem of using atomic energy in chemistry, physicochemical support of nuclear power engineering, studying the structure and properties of polymers, creating scientific bases for the selection of catalysts, especially for the catalytic processing of oil and natural gases, the use of highly efficient oxidants for reactive technology, research properties of semiconductors, etc. The main results of the Institute, in particular, on the theory of chemical processes, in the mid-1950s were at the level of modern world science [7], "but in general the level of our research was lower than in many institutions abroad," noted the director of NIFHI, Professor P.I. Zubkov at the meeting of the party-economic asset in May 1955 [8]. The experience of NIFHI laboratories showed that the attempt to solve several problems by small forces did not give enough effect. Academician V.A. Kargin believed that the main difficulty was in the absence of approaches and ideas. He noted that "this has always been a bottleneck. When we talk about developing a theory, it is a matter of time, since it takes years to do it"[9].

A hard-to-overcome circumstance in the expansion of scientific and technical contacts was the existence of "strict secrecy" developments. Ideological confrontation created conflicting judgments and actions, including among the employees of NIFHI. A member of party activists, I. Gilman, speaking at the meeting, noted about the "hostile capitalist environment" and the need to observe strict state secrets, but at the same time, spoke about the great danger that hidden works, cultivating stagnation, backwardness in work. The personal example of I. Gilman, a research fellow at NIFHI, 
was an anecdotal case. The search for the necessary report on the topic, long troubles for two months led him to the indicated institution, where he was informed that the report was sent to NIFHI, and this was the work of this particular institution [10].

The minutes of party meetings and scientific councils reflect the rather serious vulnerability of the domestic scientific community in conditions of ideological confrontation.

\subsection{Technology Transfer Organizational Mechanism}

The documents, studied by the authors, illustrate the attempts to overcome the emerged contradictions by authorities. On November 16, 1957, the State Scientific and Technical Committee (SSTC) of the USSR Ministry of Foreign Affairs and the Ministry of Foreign Trade adopted the instruction of the Ministry of Chemical Industry on the procedure to purchase new equipment abroad. According to the document, vehicles, equipment, instruments, mechanisms, whose technical characteristics significantly exceeded the analogues of domestic samples or previously purchased abroad, fundamentally new technologies and materials were subject to transfer. The Ministry of Foreign Trade purchased samples of new equipment abroad at the request of the SSTC of Union republics, ministries and departments of the USSR after the SSTC of the USSR established the expediency of their procurement. [11] Thus, in 1959 the Ministry of Chemical Industry ordered the Ministry of Foreign Trade to find out the possibility of importing necessary samples of protective equipment and devices for working with radioactive substances in nuclear power engineering [12]. An important link in this chain was the testing of new equipment by Soviet specialists directly at enterprises and the provision of data to SSTC protocols on the results of the experimental application of samples of new equipment. The established tight deadlines (within a month) for transfer tests were the most important component of the very idea of borrowing technologies. The issue of the transfer was discussed at the level of central government bodies, including various ministries and departments. The issues of control over incoming information from advisers on science and technology in Embassies of the USSR abroad were most important. By the decision of the Council of Ministers of the USSR of January 14, 1958, No. 56-24c (secretly), the control of activities of advisers in science and technology of Embassies was entrusted to the State Scientific and Technical Complex of the USSR [13]. As agreed with the Ministry of Foreign Affairs of the USSR, highly qualified specialists were sent to work at the embassy to study achievements of foreign science and technology. At the same time, the strict control was established over the use of technical documentation, materials received from advisors.

The Ministry of Foreign Trade issued special instructions to trade missions abroad to assist them in advising Soviet science and technology advisors in organizing visits to individual firms and enterprises, as well as in obtaining technical information. The Soviet specialists, sent abroad to study foreign experience, were supervised by Soviet science and technology advisors. The Ministry of Finance of the USSR provided funds necessary to purchase scientific and technical literature for representation expenses in estimates of Embassies abroad [14]. The technology transfer between member countries of the Council for Mutual Economic Assistance (CMEA) was carried out through a permanent commission for coordination of scientific and technical research. The cooperation of the CMEA member countries took place through the main scientific research and design organizations, was of a permanent nature. However, in the process of drawing up plans for joint work of the USSR-CMEA, materials were collected on the current scientific level and the state of work on these issues in capitalist countries [15]. The style of relations, in many ways, was determined by the political factor. Agreeing with the researcher E. Kochetkova, we note that "for the USSR, the cooperation with the capitalist state, in which the transfer was made, was an indicator of the ability to" peaceful coexistence ", and the adopted form of the technology transfer (trips of Soviet specialists, namely, the correct behavior of Soviet citizens) was considered as the popularization of "true" knowledge about Soviet reality in the West "[6]. One of the most important components of the transfer was the process of registration of a specialist for a business trip. The fieldwork consisted of a rather impressive list of documents: an autobiography in two copies, written by hand; questionnaires in two copies, written by hand; a personal data sheet in four copies, typed on a typewriter; certificates of health in two copies, photographs in the amount of 12 pieces; characteristics in triplicate, signed and approved by the Central Committee of the Communist Party [16]. The specialists were sent for personal acquaintance with scientific achievements and exchange of experience, since a large number of scientific developments were not published in international journals. In turn, the articles of Soviet scientists should not contain information forbidden for publication in the open press by the Resolution of the Council of Ministers of the USSR of April 26, 1956, the Glavlit list of 1960 and the list of the USSR Academy of Sciences dated June 30, 1959 [17].

\subsection{Analysis of the correspondence of Soviet scientists with foreign colleagues}

A significant number of archival documents - correspondence with foreign scientists on the exchange of scientific papers, ideas are of great interest for understanding the involvement of researchers in the transfer process. The analysis of the correspondence demonstrates the close ties of scientists with foreign colleagues. Senior Researcher of NIFHI, V.V. Tolmachev in the memo asked for permission to send prints of his articles abroad and to have the possibility of receiving foreign authors' articles in return. The address list included the United States, the Netherlands, France, Australia, England, just 12 addresses. The copies of these letters were sent on August 12, 1961. The texts of letters to foreign colleagues were coordinated with the foreign department of the State Committee for Chemistry. In addition, the editors sometimes "corrected" the text at their discretion [18]. Often, through correspondence, the scientists agreed on a 
possible exchange of technology. In a letter to the research assistant A. Piskunov, a request was made to send a description of the paramagnetic resonance system developed at the British firm Microvei Instruments [19]. The establishment of personal ties of scientists from different countries allowed more efficient use of technology. In contract No. 69/1756 of December 14, 1960 with the British firm Polymer Consultants Limiter and Mashpriborintorgom for the supply of instruments for studying light scattering in the USSR, additional clarifications were made in a personal letter from the research officer of NIFHI, Yu. Vyrsky: "... I will be very thankful for all the tips and directions you could give regarding the details of the device. We really need the ordered equipment... Please keep me updated on your new developments in the field of modern polymer research methods" [20]. The cooperation of Soviet and foreign scientists was carried out in the joint publication of scientific monographs. The proposal of V. Gold, Professor of the University of London Royal College, working in the field of studying physical organic chemistry, with the request to write an article for the first volume "Successes in Physical Organic Chemistry", was received by A. I. Shatenstein, Professor of NIFHI, in 1962. The confirmation of the possibility to accept the proposal of Professor W. Gold was obtained by Professor Ya. M. Kolotyrkin, from the director of NIFHI. The reply letter of A.I. Shatenstein was grateful for the invitation to be among the authors of the first volume of the publication, which "certainly will be accepted by chemists of different countries with great interest" [21]. Regularly published by the publishing house of foreign literature, the bibliographic bulletin "New books abroad" allowed scientists to partially track scientific research in the world, and this helped to identify duplicated works [22]. Some of scientific discoveries of English scientists in the field of chemistry, published in the open press in the Journal of the Chemical Society in 1961, were earlier made in NIFHI, as reported Professor A.I. Shatenstein in the letter to Dr. Ibborn and Dr. Taylor, enclosing impressions with information about the work done. The dialogue was about the possibility of closer contacts in order to avoid duplication of scientific work [23]. In the letter to Mr. Commen, the head of the American firm, who translated the book of A.I. Shatenstein "Isotopic exchange and substitution of hydrogen in organic compounds", the Soviet scientist informed that he got the copy of his book and expressed the hope for "strengthening scientific contacts between our countries" [24]. The "golden twentieth anniversary" for Soviet scientists contributed to the integration into the world scientific community of domestic researchers and the formation of the phenomenon of "big science".

\subsection{Features of technological modernization in the conditions of the "cold war»}

The variety of forms of the scientific and technical interaction with the West in the 1950s-1960s undoubtedly provided the USSR with integration with the world scientific community. The essential role in the development of the concept of Khrushchev's modernization, in contrast to Stalin's mobilization, was provided by the state of the "thaw", when the protection of national interests was in interaction with the world economy. The tasks of technological modernization were decided from the positions of yesterday and tomorrow. But the "cold war" kept administrative, directive features set in the pre-war period. It seemed that military expenditures were the most important condition for the social well-being of citizens, and the military budget was seen as a factor of increasing social welfare, since it allowed the state to perform functions to protect its citizens from external enemies [25]. Finally, it should be noted that the idea of limited borrowing of Western technological experience while preserving the "primordially Russian" system of government, nevertheless, was adjusted in the 1950s-1960s to overcome ideological biases regarding the circulation of knowledge, technology and scientific ideas.

\section{Conclusion}

Thus, the study of modernization processes in the USSR in the 1950s-1960s cannot be complete if we do not take into account the importance of the technology transfer and international cooperation. Major structural changes in the world economy in the mid-1950s, mainly in the United States, largely served as a guide for the choice of the strategy of the scientific and technical partnership of the USSR with the outside world. It is noteworthy that during the search for directions of this interaction, the political elite of the USSR chose as examples the experience of both socialist and capitalist countries. At the same time, the political factor determined the nature of these relations. The cooperation with the countries of the socialist bloc was permanent in the framework of the CMEA, coordinated by the main scientific research institutes and design organizations through established open reporting forms on the volume of work performed. The strategy of the interaction with capitalist countries was built against the backdrop of serious efforts of the Soviet political etiology to present the cooperation as solely achievements of the Soviet science and technology. Most of ministerial and departmental decrees and orders under the label "secret", "top secret", in the documents of NIFHI evidenced political and ideological confrontation. At the same time, the desire of state bodies to ensure access of Soviet researchers to Western developments is a confirmation of the fact that it was possible to get effective results only in the cooperation. During the period under study, scientists were able to regularly take part in international scientific events, publish joint articles and monographs, maintain regular correspondence with colleagues, and jointly master new technologies. The logic of such relationships, as the documents examined show, was built not only within the framework of the implementation of party decisions, but also preceded from research interests of scientists. The existing objective prerequisites, even in conditions of ideological confrontation, contributed to the active networking of the scientific community. 


\section{References}

1. T. Luke, Technology and soviet foreign trade. International Studies Quarterly, 29(3), 327-353. URL: https://www.jstor.org/stable/2600488?seq=1\#page scan tab_contents (1985).

2. A.C. Sutton, Western technology and soviet economic development 1945 to 1965. Stanford, California, USA: Stanford University (1973).

3. S. Autio-Sarasmo, N. Katalin, Reassessing Cold war Europe. New York, NY: Taylor \& Francis Croup (2011).

4. S.V. Kuvshinov, Scientific and technical policy of the USSR in the field of the technology transfer in the era of postwar modernization. The mid-1940s - the mid-1950s. Extended abstract of PhD dissertation. Moscow: Russian State University for the Humanities (2012).

5. A.A Kapitonov, E.A. Solentzova, The concept of the history of transfers in modern historical research. Bulletin of Samara State University of Economics, 5(115), 112-116 (2014).

6. E.A. Kochetkova, Modernization of the Soviet pulp and paper industry and the technology transfer in 1953-1964: the case of Enso-Svetogorsk. Laboratorium, 5(3), 13-42. URL: https://cyberleninka.ru/article/n/modernizatsiyasovetskoy-tsellyulozno-bumazhnoy-promyshlennosti-i-transfer-tehnologiy-v-1953-1964-godah-sluchay-ensosvetogorska (2013).

7. Russian State Archive in Samara (RSA in Samara). F. R - 16. Op. 4-6. D. 133. L. 32.

8. RSA in Samara. F. R- 16. Op. 2-6. D. 384. L. 7.

9. RSA in Samara. F. R- 16. Op. 2-6. D. 384. L. 75.

10. RSA in Samara. F. R- 16. Op. 2-6. D. 384. L. 117-118.

11. RSA in Samara. F. R- 16. Op. 4-6. D. 148. L. 2-21.

12. RSA in Samara. F. R- 16. Op. 4-6. D. 148. L. 32.

13. RSA in Samara. F. R- 16. Op. 4-6. D. 148. L. 24-25.

14. RSA in Samara. F. R- 16. Op. 4-6. D. 148. L. 25.

15. RSA in Samara. F. R- 16. Op. 2-6. D. 697. L. 10-18.

16. RSA in Samara. F. R- 16. Op. 2-6. 621. L. 59.

17. RSA in Samara. F. R- 16. Op. 2-6. D. 662. L. 536.

18. RSA in Samara. F. R- 16. Op. 2-6. D. 616. L. 18. 25.

19. RSA in Samara. F. R- 16. Op. 2-6. D. 614. L. 21.

20. RSA in Samara. F. R- 16. Op. 2-6. D. 616. L. 287.

21. RSA in Samara. F. R- 16. Op. 2-6. D. 662. L. 133.

22. RSA in Samara. F. R- 16. Op. 2-6. D. 616. L. 10.

23. RSA in Samara. F. R- 16. Op. 2-6. D. 616. L. 206-207.

24. RSA in Samara. F. R- 16. Op. 2-6. D. 662. L. 407.

25. V.N. Paramonov, Russia in 1941-1945: Problems of industrial development. Samara: Samara University Publishing House (1999). 